7. Bacilly B. Remarques curieuses sur l'art de bien chanter / B. Bacilly. - Paris, Covell R. Voice Register as an Index of Age and Status in Opera Seria //Opera \&Vivaldi. - University of Texas, 1984. - P. 193-210.

8. Quantz J. Versuch einer Anweisung die Flote traversiere zu spielen / J. Quantz; Berlin, 1752. Tr. and ed. by Edward Reilly as On Playing the Flute. - New York, 1982.

Лобода Л. Функциональные и семантические свойства голосового регистра в опере эпохи барокко. В статье рассматриваются вопросы, связанные с функциональными и семантическими свойствами голосового регистра эпохи оперы барокко. На основе исполнительской и педагогической деятельности мастеров барочного bel canto прослеживаются черты универсальной вокальной школы, которая была зафиксирована в теоретических трактатах.

Ключевые слова: барокко, bel canto, исполнительские школы, голосовой регистр, вокальные педагогические системы.

Loboda L. Functional and semantic properties of the vocal registers in operas of Baroque. The article deals with issues related to functional and semantic properties voice register Baroque era opera. Based on the performance and teaching of the masters of baroque bel canto lines are traced universal vocal school, which was recorded in theoretical treatises.

Keywords: baroque, bel canto, performing schools, vocal register, vocal pedagogical system.

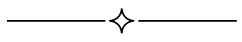

УДК 78.01+78.071.2

И. Чирка

\title{
ПРОЦЕСС СОЗДАНИЯ ОРКЕСТРОВОЙ ТОЧКИ-ЗВУКА КАК ВАЖНОЙ СОСТАВЛЯЮЩЕЙ ДИРИЖЕРСКОГО ИСПОЛНИТЕЛЬСТВА
}

Статья посвящена рассмотрению актуальных вопросов дирижерского искусства, среди которых наиболее важной оказывается проблема дирижерского жеста. Процесс создания точки-звука в процессе исполнительства соотносится с интонационной теорией.

Ключевые слова: дирижерское искусство, дирижерский жест, интонация, мануальная техника, точка-звук.

Музыкальное исполнительство на протяжении всей своей истории развития предстает как сложный коммуникативный феномен, в котором все участники диалога находятся в постоянном творческом

(С) Чирка И., 2014 
общении. Так, в музыкально-исполнительском процессе круг участников достаточно широко очерчен, и в качестве реципиентов творческого диалога можно назвать композитора, исполнителя, слушателя, если речь идет о сольном исполнительстве, в случае оркестрового исполнительства одним из наиболее заметных участников диалога следует назвать дирижера. Обозначенная проблема практически не разработана в современном музыкознании, что и становится залогом актуальности данной статьи.

В исполнительском коммуникативном акте особое место занимает творческая индивидуальность дирижера и его «инструмент» - дирижерский жест. Как указывают многие исследователи, именно дирижерский жест аккумулирует самые значительные и эффективные средства и методы руководства группой исполнителей и оказывает на них особое художественное воздействие. Важно отметить, что в современном дирижерском исполнительстве главенствующее значение имеет эффективность в передаче образного содержания произведения. Свое основание и аргументацию данное утверждение находит в исследовании феномена дирижерского жеста, который является главным средством общения, творческой коммуникации и едва ли не единственной возможностью сообшения оркестрантам информации о прочтении произведения дирижером.

Вместе с тем художественная сфера дирижерского жеста как «инструмента» отличается многоаспектностью и абстрактностью, поясняющей множественность ее возможных трактовок. Поэтому вопросы, связанные с ролью дирижерского жеста и его функциями в достижении художественного результата в процессе коллективного исполнения, до сих пор являются предметом довольно серьезных дискуссий. Среди наиболее проблемных зон можно назвать обсуждение художественных функций и структурных характеристик дирижерского жеста, возможность передачи им художественного содержания в качестве автономного самодостаточного инструмента.

Среди приверженцев теории, согласно которой дирижерский жест может трактоваться как основной инструмент в достижении высокого художественного смысла в оркестровом исполнительстве, можно назвать М. Багриновского. Автор указывал, что никакие подробные словесные объяснения, равно как и примечания и пометки в нотном тексте, не могут обеспечить достижения требуемого эффекта и «желаемого уровня исполнения, если дирижер не владеет мануальной техникой» [2, с. 34]. С помощью мануальной техники и ее худо- 
жественного воздействия дирижер может преодолеть разрозненность исполнителей-оркестрантов, их некоторую пассивность ради достижения целостного творческого акта.

Чрезвычайно высокий уровень современного исполнительского искусства предъявляет высокие требования к личностным и творческим качествам дирижера, качество исполнительской деятельности которого напрямую зависит от совершенства его мануальной техники и точности жеста. Однако именно художественные качества дирижерского жеста являются проблемной зоной, так как, как указывал И. Мусин, «все затруднения, вопросы, проблемы и разногласия связаны именно... с мануальными средствами руководства выразительной стороной исполнения. Именно она и является камнем преткновения не только для желающих заниматься дирижированием, но и для понимания природы, структуры и содержания мануальных средств» $[4$, с. 9].

Как и любое другое языковое устройство, язык жестов имеет свои индивидуальные черты. Так, каждый дирижер в процессе творческой коммуникации с оркестром использует в равной степени комплекс общепринятых дирижерских приемов и группу приемов, являющихся авторскими и характерными именно для творческой индивидуальности конкретного дирижера. Иными словами, авторские средства являются результатом деятельности данного дирижера, то есть «особым специфическим видом творчества» [4, с. 15]. Это вполне соотносимо с традиционным толкованием понятия «творчество», которое представляет собой сознание, буквально - творение принципиально новых культурных ценностей, отличающихся оригинальным решением и неповторимым выражением [7].

Следовательно, согласно трактовке И. Мусина язык дирижерских жестов предстает как особое средство художественного воздействия, как творческий результат дирижерского исполнительства, что позволяет указывать на автономное художественное значение данного феномена. В свою очередь, рад других исследователей выстраивают концепцию художественной функции дирижерского жеста с позиции отношения его к музыкальному тексту (например, в работах К. Ольхова, Д. Варламова и др.). Так, К. Ольхов, рассуждая о связи дирижерского жеста и музыки, говорит о том, что, наблюдая за жестами, «можно приблизительно представить себе и соответствующую им музыку» [5, с. 28]. Сообщая через жест коллективу исполнителей звучание, представляемое дирижером во всех деталях в его внутрен- 
нем слышании, дирижер передает «свою мысленную модель на жест и мимику: слуховая модель превращается в зримую» [5, с. 30].

Иными словами, моделируемое дирижером музыкальное содержание является объектом подражания для исполнителей, а мануальная модель представляет собой не просто средство отображения музыкального содержания, но и средство его действенного воплощения, преобразования.

Дирижерский жест состоит в первую очередь из графически точной организации ауфтакта - замаха, стремления в точку, к точке-звуку и его отражению. В данной работе хочу обратить особое внимание на процесс создания точки. Ведь эта фаза отвечает за главное в дирижерском искусстве - момент возникновения звука. Какой должен быть тембр звука, его характер, каким штрихом исполняется звук, за все эти качества отвечает правильная организация дирижером - точки.

Все размышления о дирижерском жесте и его творческой предназначенности следует начинать с самого начала обучения и подготовки дирижеров, так как основы исполнительской трактовки дирижерского жеста закладываются именно в этом процессе. Дирижируя в классе, начинающий дирижер пытается создавать звучание-точку одновременно или после возникшего звука на инструменте. В этом случае дирижер подыгрывает, аккомпанирует инструменту - воображаемому оркестру. Таким образом, момент возникновения звука-точки совпадает с точкой-атакой оркестра, а может быть, и позже. Это говорит о том, что молодой дирижер эмоционально чувствует музыкальный материал, но не ощущает формы произведения, оказывается в полной динамической и ритмической зависимости от оркестра.

Таким образом можно констатировать, что реакции в его сознании в данном виде деятельности проходят с опозданием, оставляя право создания интонационного облика произведения и создания целостного художественного образа оркестру. Это крайне неверная предпосылка, так как оркестр может некоторое время продолжать озвучивать нотный текст, но в таком случае говорить о создании исполнительской трактовки и интерпретации произведения невозможно. Нельзя забывать о главном назначении дирижера - быть интерпретатором звучащей среды, то есть сообщить необходимую информацию оркестрантам о звуке и его характере в мотиве, фразе, периоде, эпизоде, части и в целом произведении.

Дирижер должен предслышать, слышать и организовывать момент возникновения звука с помощью дирижерской техники. На 
первом этапе обучения необходимо научить молодого дирижера мыслить, давать возможность не бояться высказывать «свое я» в мануальной технике, связанной с мышлением, сознанием, созданием образа. Иными словами, даже в процессе обучения есть насущная потребность в постоянном напоминании о том, что он дирижирует оркестром. Педагог должен контролировать этот процесс и направлять обучение в классе в сторону реальной, практической работы с музыкантами оркестра.

Для понимания того, какие мышцы участвуют в процессе создания точки, необходимо сначала обратиться к ауфтакту. Первоначальное положение - руки опущенные вниз, потом приподнимаем их до уровня пояса и не выше, не ниже, параллельно полу, немного сгибаем в локтях, подаем вперед. Контролируем себя с помощью зеркала, запоминаем это положение рук. Оно должно быть удобным и естественным. Делаем замах лицевой частью ладони, ощущение звука должно быть в этой части руки. Следим за тем, чтобы локоть, плечо мышечно были расслаблены и без препятствий шли за лицевой частью ладони. Чтобы понять, до какой точки вверх необходимо вести руки, где остановиться, необходимо задать нужный темп, необходимый для данного произведения.

В процессе начальной подготовки есть ряд необходимых процедур, соблюдение которых может существенно облегчить постижение премудростей дирижерского искусства. Среди подобных достаточно простых рекомендаций можно указать на необходимость обязательного просчитывания в процессе знакомства с партитурой произведения (раз «И», два «И», три «И», четыре «И», в зависимости от размера произведения, с которым вы работаете). Это следует делать потому, что вторая часть счетной доли зачастую руками не доводится до конца, и поэтому счетная доля неполная и недоигрывается оркестром. Далее следует вторая часть дирижерского жеста - стремление в точку. Теперь ощущение звука переносится во внутреннюю часть ладони и на кончики пальцев, в зависимости от того, какую точку мы хотим организовать: нажим - звук в ладони, ближе к кисти; скольжение, удар, острое касание - звук на кончиках пальцев. Далее руки движутся к точке, где возникает звук. Важно, чтобы точка была в том месте, откуда мы делали замах, то есть в первоначальном положении и не ниже, и не выше.

Расстояние между замахом и стремлением должно бать одинаковым, потому что в сумме они дают счетную долю. Для организации точки в первой, второй, третьей, четвертой долях полезны следующие 
упражнения. Для организации первой доли необходимо начинать дирижирование со второй доли, то есть обязательно просчитывать два «И», три «И», четыре «и». За счет «и» четвертой доли формируем ауфтакт к первой доле. Если точно сохранять темп, дирижируя со счетом вслух, вы правильно выполните начальный ауфтакт и точку к четвертой доли. Для организации второй доли начинать дирижирование с третьей доли, выполняя вышеуказанные требования, и так далее. Полезность этого упражнения заключается еще в том, что обучаемый запоминает исходное положение и направление рук, необходимое для первой, второй, третьей, четвертой доли четырехдольного размера, главное вы сможете выполнить точку - начало звука с любой доли такта. Те же упражнения можно проделать с простыми, сложными и смешанными метрами - тактовыми схемами.

Ранее указывалось, что проговаривая «и» в каждой доле такта мы сохраняем полную счетную долю, однако значение этого элемента заключается еще и в том, что за счет «и» формируется замах, ауфтакт к метрическим долям. А главное, проговаривая «и», молодой дирижер получит и прочувствует правильность выполнения четвертой фазы дирижерского жеста - отражения, в которой «и» выполняет функцию последующего звуковедения, роль междольного замаха и подготавливает следующую долю.

Как указывает К. Ольхов, основой любого ауфтакта является некий импульс, реализующийся в ускоряющемся движении. Движение, возникающее вследствие ауфтакта, обладает специфической побудительностью, импульсивностью, воспринимается как побуждение к действию [5, с. 84]. Примечательно, что при изучении структуры ауфтакта еще один исследователь, И. Мусин, в описании побуждающей силы движения также использует понятие «импульс», однако несколько в ином ключе. Исследователь использует его для определения начала движения - точки.

Следовательно, подытоживая проведенные исследования в этой сфере, можно сделать вывод о том, что ауфтакт состоит из ряда связанных движений, каждое из которых представляет собой импульс к действию. В ряду импульсов, сменяющих друг друга и побуждающих исполнителей к постоянной игровой активности, следует назвать импульс-замах, импульс-стремление, импульс-удар (импульс-точка), импульс-отражение.

Исследование принципа воздействия дирижерского знака приводит многих исследователей, в частности Б. Смирнова, к концепции 
жеста-действия. По мысли исследователя, основу дирижерского искусства составляют принципы коммуникативного и художественного воздействия и каждое движение дирижера представляет собой потенциальное активное действие. Дирижерские действия передают информацию, тогда как воздействие подчиняет волю исполнителей. Все представленные уровни управления (эмоционально-выразительное движение, действие, воздействие) способствуют существованию коммуникативного творческого взаимодействия участников коллектива [6, с. 89-99].Иными словами, Б. Смирнов рассматривает дирижерский жест не только как воздействие на коллектив, не только импульс, вызывающий игровые действия исполнителей, но и как само действие, с помощью которого дирижер способен создавать собственную интерпретацию произведения, а главное, становится исполнителем. Это подтверждает мысль о художественном значении и исполнительской самостоятельности дирижера.

Дирижерский жест как пластический феномен интонационен по своей сути, и, обсуждая понятия «интонации жеста», исследователи указывают на данное понятие как на важнейшее средство дирижерского «инструмента». Моторность в интонации является главным показателем ее эмоциональной выразительности, а образность дирижерского жеста проявляется в основном через пластическое выражение им интонационного содержания музыки, через его интонацию.

На близость интонации и жеста указывал В. Медушевский: «Уже единичный звук, взятый в совокупности всех его сторон - высоты, длительности, тембра, тесситуры, громкости, артикуляции - представляет собой знак - интонацию. <...> Также синкретически-целостно объединяют в себе разные стороны пластические знаки, воспроизводящие жест, движение» [3, с. 12]. Б. Асафьев же указывает, что каждая эпоха вырабатывает особые интонации, которые непосредственно связаны с конкретными образами, аффектами, идеями, ощущениями и с которыми интонации существуют в непосредственном взаимодейсвии. В результате этого между данными явлениями и созвучными им интонациями образуются устойчивые ассоциации, «не уступающие смысловой словесной семантике. Звуковой образ интонация, получившая значение зримого образа или конкретного ощущения, - вызывает сопутствующие ему представления» [1, c. 207].

Таким образом, эмоции, вызванные через глубинное ощущение дирижером интонационного содержания музыкального образа, при- 
водят к активации его воображения, а следовательно, и его ассоциативной памяти. Последняя, в свою очередь, направлена на поиск нужных психических, а затем мышечных ощущений образного содержания, которые способствуют нахождению необходимых выразительных жестов. Следовательно, дирижерское искусство представляет собой не только некое средство выразительности, оно способно передавать и создавать интонацию, рождать звук.

\section{СПИСОК ЛИТЕРАТУРЫ}

1. Асафьев Б. В. Музыкальная форма как процесс : Кн. 1 и 2 / Б. В. Асафьев. - 2-е изд. - Л. : Музыка, 1971. - 376 с.

2. Багриновский М. М. Дирижерская техника рук / М. М. Багриновский. - М. : Высшее училище военных дирижеров Советской Армии, 1947. $295 \mathrm{c}$.

3. Медушевский В. В. О закономерностях и средствах художественного воздействия музыки / В. В. Медушевский. - М. : Музыка, 1976. - 385 с.

4. Мусин И. А. Язык дирижерского жеста / И. А. Мусин. - М. : Музыка, 2006. $-232 \mathrm{c}$.

5. Ольхов К. А. Вопросы теории дирижерской техники / К. А. Ольхов. Л. : Музыка, 1979. - 160 с.

6. Смирнов Б. Ф. Дирижерско-симфоническое искусство : музыкально-эстетические и социально-психологические аспекты : [монография] / Б. Ф. Смирнов. - 2-е изд. - СПб. : Композитор, 2012. - 295 с.

7. Философский словарь / А. И. Абрамов и др. ; [под ред. И. Т. Фролова]. - М. : Республика, 2001. - 719 с.

Чирка І. Процес створення оркестрової точки-звуку як важсливої складової диригентського виконавства. Стаття присвячена розгляду актуальних питань диригентського мистецтва, серед яких найбільш важливою виявляється проблема диригентського жесту. Процес створення точки-звуку в процесі виконавства співвідноситься з інтонаційною теорією.

Ключові слова: диригентське мистецтво, диригентський жест, інтонація, мануальна техніка, точка-звук.

Chirka I. Creating point orchestral sound as an important part of playing a conductor. The article considers current issues conductor's art, among which the most important is the problem of the conductor's gesture. The process of creating pointsound in the process of performing correlates with intonation theory.

Keywords: conducting art, conductor gesture, intonation, manual technique, point-to-sound. 